Vol. 11 (2002): 153-161.

\title{
Yield formation of spring rye at high latitudes with reference to seeding rate and plant growth regulation
}

\author{
Pirjo Peltonen-Sainio, Ari Rajala and Susanna Muurinen \\ Department of Applied Biology, PO Box 27, FIN-00014 University of Helsinki, Finland. Current address: \\ MTT Agrifood Research Finland, Plant Production Research, FIN-31600 Jokioinen, Finland, \\ e-mail: pirjo.peltonen-sainio@mtt.fi
}

\begin{abstract}
Aspects of crop physiology and agronomy of spring rye were evaluated at Viikki Experimental Farm, University of Helsinki in 1996-1998 to get baseline information on its potential as a novel cereal crop in southern Finland. The German spring rye cultivar Ovid was fertilized with $80 \mathrm{~kg} \mathrm{~N} \mathrm{ha}^{-1}$. Seeding rates were 300,500 , and 700 viable seeds $\mathrm{m}^{-2}$. Chlormequat chloride (CCC) was sprayed at the two-node stage of the main shoot and its effects on lodging and yield formation were studied. Various traits were assessed that characterised tiller and main shoot growth and productivity, growth duration and plant stand structure. Spring rye responded differently over years and among CCC treatments. CCC increased grain yield by about $200 \mathrm{~kg} \mathrm{ha}^{-1}$ compared with the control. Spring rye has long straw $(130-140 \mathrm{~cm})$ and tended to lodge under heavy rainfall. Thus, grain yield was maximum (ca. $5200 \mathrm{~kg} \mathrm{ha}^{-1}$ in 1997) when rainfall was minimum. Partly because high seeding rates enhanced lodging, no seeding rate effects on grain yield were recorded. At 300 seeds $\mathrm{m}^{-2}$, yield formation of both main shoot and tillers was enhanced to compensate for the reduced number of main shoots $\mathrm{m}^{-2}$. Ripening was not delayed at low seeding rates. Grain and hectolitre weights were not affected by seeding rate. Thus, spring rye is a potential crop for Finland if low seeding rates are used.
\end{abstract}

Key words: crop yield, lodging, precipitation, sowing rates, Secale cereale, stems, tillering, yield components

\section{Introduction}

In Finland the harvested area of autumn sown rye (Secale cereale L.) fluctuates greatly from year to year. For example, during the last decade it ranged from 9,000 to 81,000 hectares (http://www.fao.org/). According to Mukula and Rantanen (1989a), the major reason for large fluctuations in harvested area in Finland is excessive precipitation in the autumn. The optimal sowing period for winter rye is brief and it may be passed not only due to heavy rains in autumn, but also due to delayed harvesting of the preceding crop. In addition, the risk analysis of Mukula and Rantanen (1989a) indicated that winter damage, flooding of fields and heavy rains at harvest, reduced the harvestable area. 


\section{Peltonen-Sainio, P. et al. Yield formation of spring rye}

In the 1990s the total annual harvested grain yield of winter rye in Finland ranged from 22,000 to $250,000 \mathrm{t}$ and the average grain yield was 2.5 t ha' ${ }^{-1}$ (http://www.fao.org/). Productivity of rye has not improved markedly during the last 50 years: the yield gains have averaged $1.38 \%$ per year, which is less than for the other cereal crops grown in Finland (Slafer and Peltonen-Sainio 2001). Even though winter rye is far better adapted than winter wheat to high latitudes (Mukula and Rantanen 1989b), problems related to sowing and over-wintering cause instability in yield formation and have yet to be overcome. Therefore, this study was done to make crop physiological and agronomic evaluations of spring rye and thereby get preliminary information about the potential of spring rye as a substitute crop for winter rye when weather conditions are unfavourable for sowing winter rye.

An important factor causing fluctuation both in yield and grain quality of winter rye is the tendency of the long-strawed cultivars to lodge (Mukula and Rantanen 1989a). Plant growth regulators (PGR) represent a method to control lodging in cereals, but experiments with PGRs have mainly focussed on wheat (Triticum aestivum L.) and barley (Hordeum vulgare L.) (Rajala and Peltonen-Sainio 2000). In winter rye, both PGR induced increase in lodging resistance or grain yield (Kurten et al. 1972, Sturm 1975, Froment and McDonald 1997) and absence of effect or yield reduction have been recorded (Heyland and Aufhammer 1973). Since the spring rye cultivar evaluated in this study was long strawed, we monitored the effects of the gibberellin biosynthesis-blocking agent, chlormequat chloride (CCC), on stem elongation, lodging resistance, tiller growth and yield formation.

Winter rye sown earlier in the autumn than winter wheat can tiller profusely prior to winter. Short days, low temperatures and high precipitation favour tiller bud release and tiller growth. In contrast to autumn sown rye, the contribution of tillers to grain yield is negligible for spring sown cereals in northern growing conditions (Mela and Paatela 1974, Peltonen-Sainio and Järvinen 1995). Thus, this study focussed on monitoring the role of tillers in yield formation of spring rye as well as studying the effects of seeding rate on tiller performance and yielding ability.

\section{Material and methods}

Field experiments were carried out at Viikki Experimental Farm, University of Helsinki, Finland $\left(60^{\circ} \mathrm{N} 13^{\prime} \mathrm{N}\right)$ in $1996-1998$. The trials were conducted with the German spring rye cultivar Ovid (supplied by Tilasiemen Oy) and were sown on 22 May in 1996, 14 May in 1997 and 21 May in 1998 . Net plot size was $10 \mathrm{~m}^{2}(1.25 \times 8 \mathrm{~m}$, $12.5 \mathrm{~cm}$ between rows). $80 \mathrm{~kg}$ of $\mathrm{N} \mathrm{ha}^{-1}$ as $\mathrm{NH}_{4} \mathrm{NO}_{3}$ was applied as a basal dressing. Weeds were controlled with MCPA [(4-chloro-2-methylphenoxy) acetic acid] and dichlorprop. A two factor (sowing rate and PGR treatment) randomised block design with four replications was employed. Sowing rate was 300, 500 and 700 viable seeds $\mathrm{m}^{-2}$ with or without CCC treatment. CCC [(2-chloroethyl)-trimethylammonium chloride] was sprayed on to the plant foliage at 1.1 $\mathrm{kg}$ a.i. ha $\mathrm{h}^{-1}$ (at $3001 \mathrm{ha}^{-1}$ ) when the second main shoot node was evident (GS32, Zadoks et al. 1974), 41, 36 and 35 days after sowing in 1996, 1997 and 1998, respectively. Soil type was tentatively classified as sandy clay.

The following morpho-physiological traits were measured on plants from each plot: 1) grain yield ( $\mathrm{kg} \mathrm{ha}^{-1}$, calculated at $15 \%$ moisture), 2) days from sowing to heading, 3 ) days from sowing to yellow ripeness, 4) length of grain-filling period (d) from heading to yellow ripeness, 5) height from soil surface to the uppermost leaf ligule $(\mathrm{cm}), 6)$ length of visible peduncle $(\mathrm{cm})$, 7) length of the head $(\mathrm{cm})$, and 8) height from soil surface to the head tip $(\mathrm{cm})$ at maturity, 9) lodging (\%) when plant stands were irreversibly lodged at post-anthesis, 10) number of heads $\mathrm{m}^{-2}$ measured from 3 rows per plot, each $0.5 \mathrm{~m}$ long, 11) main shoot phytomass (g), 12) main shoot vegetative phytomass $(\mathrm{g}), 13)$ main shoot head 
Vol. 11 (2002): 153-161.

weight ( $\mathrm{g}$ ) as a total weight of grains per head, 14) tillers per main shoot (no.), 15) head-bearing tillers per main shoot (no.), 16) vegetative phytomass on tillers ( $g$ per main shoot), 17) total weight of grains on tiller heads (g per main shoot), 18) contribution of tillers to grain yield $(\%)$ as a proportion of grain yield per plant produced by head-bearing tillers, 19) main shoot HI (harvest index, \%) as a proportion of total weight of grains over phytomass, 20) single grain weight $(\mathrm{mg}), 21)$ number of grains per main shoot head, 22) main shoot head-filling rate (HFR, mg per head $\mathrm{d}^{-1}$ ), and 23) main shoot grain-filling rate (GFR, mg per grain $\mathrm{d}^{-1}$ ). Traits 11 to 21 were measured from 40 randomly sampled mature plants in each plot. Traits 14 to 18 were measured only in 1997 and 1998.

Statistical significances of differences between the effects of year, sowing rate and PGR treatment for grain yield and morpho-physiological traits were established using the SAS Mixed Procedure (Littell et al. 1996). Differences at P $<0.05$ among least significant means were established.

\section{Results}

Year $\left(\mathrm{F}_{2}=454, \mathrm{P}<0.001\right)$ and CCC treatment $\left(\mathrm{F}_{1}=7.97, \mathrm{P}<0.007\right)$ significantly affected grain yield of spring rye, whereas seeding rate had no effect $\left(\mathrm{F}_{2}=0.59, \mathrm{P}<0.556\right)$. The grain yield ranged from about $2,000 \mathrm{~kg} \mathrm{ha}^{-1}$ in 1998 to 5,400 $\mathrm{kg} \mathrm{ha}^{-1}$ in 1997 , about a mean of $3,480 \mathrm{~kg} \mathrm{ha}^{-1}$. The number of days from sowing to heading differed significantly among years $\left(\mathrm{F}_{2}=1878, \mathrm{P}<\right.$ $0.001)$. Time to maturity also differed $\left(\mathrm{F}_{2}=9262\right.$, $\mathrm{P}<0.001)$ as did length of grain-filling period $\left(\mathrm{F}_{2}=285, \mathrm{P}<0.001\right)$. In 1997, growth phases were short (Table 1), but weather conditions (Table 2) favoured yield formation. In 1997, the main shoot head weight and HI were far higher than in the other two years and were associated with higher number of grains per head (Table 3). In 1997, plant stands principally consisted of main shoots, and the numbers of heads per square meter were $49 \%$ and $31 \%$ lower than in 1996 and 1998, respectively. Production of vegetative phytomass did not differ greatly from year to year. The height of plant stands varied from $130 \mathrm{~cm}$ to $139 \mathrm{~cm}$ depending on year (Table 4).

Use of CCC increased grain yield of spring rye by about $200 \mathrm{~kg} \mathrm{ha}^{-1}\left(\mathrm{~F}_{1}=7.97, \mathrm{P}<0.007\right)$. This was not due to CCC induced delay in ripening, as no consistent and marked effects on duration of pre- and post-heading periods were recorded (Table 1). CCC slightly reduced plant height (by 1-6\% depending on year, Table 5). This was particularly due to inhibition of elongation of the visible part of the uppermost internode, peduncle, whereas the effects of CCC on head length and height to the uppermost leaf

Table 1. Seeding rate and CCC treatment effects on growth duration of spring rye in 1996-1998. Means within each year and treatment not followed by the same letter are significantly different at $\mathrm{P} \leq 0.05$.

\begin{tabular}{|c|c|c|c|c|c|c|c|c|c|}
\hline \multirow[t]{2}{*}{ Treatment } & \multicolumn{3}{|c|}{ Days to heading } & \multicolumn{3}{|c|}{ Days to yellow ripeness } & \multicolumn{3}{|c|}{ Grain-filling period (d) } \\
\hline & 1996 & 1997 & 1998 & 1996 & 1997 & 1998 & 1996 & 1997 & 1998 \\
\hline \multicolumn{10}{|l|}{ Seeds $\mathrm{m}^{-2}$ : } \\
\hline 300 & $42 \mathrm{a}$ & $35 \mathrm{a}$ & $47 \mathrm{a}$ & $99 \mathrm{a}$ & $89 \mathrm{a}$ & $105 \mathrm{a}$ & $57 \mathrm{a}$ & $54 \mathrm{a}$ & $58 \mathrm{ab}$ \\
\hline 500 & $41 \mathrm{~b}$ & $35 \mathrm{a}$ & $47 \mathrm{a}$ & $98 \mathrm{ab}$ & $88 \mathrm{~b}$ & $105 \mathrm{a}$ & $58 \mathrm{a}$ & $53 \mathrm{ab}$ & $58 \mathrm{ab}$ \\
\hline 700 & $41 b$ & $35 \mathrm{a}$ & $46 a$ & $98 b$ & $88 b$ & $105 \mathrm{a}$ & $58 \mathrm{a}$ & $53 b$ & $59 \mathrm{a}$ \\
\hline \multicolumn{10}{|c|}{ PGR treatment: } \\
\hline Control & $41 \mathrm{~b}$ & $35 \mathrm{a}$ & $47 a$ & $99 a$ & $88 \mathrm{~b}$ & $105 \mathrm{a}$ & $58 \mathrm{a}$ & $53 a$ & $58 \mathrm{a}$ \\
\hline $\mathrm{CCC}$ & $42 \mathrm{a}$ & $35 \mathrm{a}$ & $47 \mathrm{a}$ & $98 \mathrm{a}$ & $89 \mathrm{a}$ & $105 \mathrm{a}$ & $57 \mathrm{~b}$ & $54 a$ & $58 \mathrm{a}$ \\
\hline
\end{tabular}

$\mathrm{PGR}=$ plant growth regulator, $\mathrm{CCC}=$ chlormequat chloride 


\section{Peltonen-Sainio, P. et al. Yield formation of spring rye}

Table 2. Monthly mean temperature $\left({ }^{\circ} \mathrm{C}\right)$ and precipitation $(\mathrm{mm})$ for growing seasons 1996,1997 and 1998 and the longterm means (1961-1990) at Kaisaniemi Meteorological Station, Helsinki.

\begin{tabular}{lcccc}
\hline & 1996 & 1997 & 1998 & Long-term \\
\hline Mean temperature: & & & & \\
May & 8.6 & 8.5 & 9.9 & 9.7 \\
June & 13.3 & 16.5 & 14.0 & 15.0 \\
July & 15 & 19.2 & 16.4 & 15.0 \\
August & 18.1 & 18.9 & 14.1 & 11.1 \\
September & 9.8 & 11.7 & 12.2 & 31 \\
Precipitation: & & & & 41 \\
May & 68 & 17 & 102 & 60 \\
June & 58 & 44 & 93 & 74 \\
July & 122 & 12 & 122 & 73 \\
August & 1 & 25 & 34 & \\
September & 28 & 52 & & \\
\hline
\end{tabular}

Table 3. Effect of year and seeding rate on main shoot phytomass, head weight, HI, grain number, and number of heads per square meter for spring rye. Means within each year or seeding rate not followed by the same letter are significantly different at $\mathrm{P} \leq 0.05$.

\begin{tabular}{cccccc}
$\begin{array}{c}\text { Vegetative } \\
\text { phytomass } \\
(\mathrm{g})\end{array}$ & $\begin{array}{c}\text { Head weight } \\
(\mathrm{g})\end{array}$ & $\begin{array}{c}\text { Phytomass } \\
(\mathrm{g})\end{array}$ & $\begin{array}{c}\text { HI } \\
(\%)\end{array}$ & $\begin{array}{c}\text { Grains per } \\
\text { head } \\
(\text { no. })\end{array}$ & $\begin{array}{c}{\text { Heads } \mathrm{m}^{-2}}_{(\text {no. })} \\
\end{array}$ \\
\hline
\end{tabular}

\begin{tabular}{ccccccr}
\hline Year: & & & & & & \\
1996 & $1.42 \mathrm{a}$ & $0.66 \mathrm{~b}$ & $2.08 \mathrm{~b}$ & $31.7 \mathrm{~b}$ & $30 \mathrm{a}$ & $1229 \mathrm{a}$ \\
1997 & $1.46 \mathrm{a}$ & $1.11 \mathrm{a}$ & $2.56 \mathrm{a}$ & $43.2 \mathrm{a}$ & $32 \mathrm{a}$ & $631 \mathrm{~b}$ \\
1998 & $1.28 \mathrm{~b}$ & $0.48 \mathrm{c}$ & $1.77 \mathrm{c}$ & $27.0 \mathrm{c}$ & $23 \mathrm{~b}$ & $921 \mathrm{~b}$ \\
Seeds m$^{-2} \mathrm{a}$ & & & & & & \\
300 & $1.53 \mathrm{a}$ & $0.81 \mathrm{a}$ & $2.34 \mathrm{a}$ & $33.5 \mathrm{a}$ & $30 \mathrm{a}$ & $798 \mathrm{~b}$ \\
500 & $1.36 \mathrm{~b}$ & $0.75 \mathrm{a}$ & $2.11 \mathrm{~b}$ & $34.3 \mathrm{a}$ & $28 \mathrm{ab}$ & $913 \mathrm{a}$ \\
700 & $1.27 \mathrm{~b}$ & $0.69 \mathrm{~b}$ & $1.96 \mathrm{c}$ & $34.2 \mathrm{a}$ & $26 \mathrm{~b}$ & $1071 \mathrm{a}$ \\
\hline
\end{tabular}

$\mathrm{HI}=$ harvest index

Table 4. Effect of year and seeding rate on height from soil surface to the uppermost leaf ligule and to the head tip and length of visible peduncle and head in spring rye. Means within each year or seeding rate not followed by the same letter are significantly different at $\mathrm{P} \leq 0.05$.

\begin{tabular}{ccccc}
\hline & $\begin{array}{c}\text { Height to } \\
\text { leaf ligule } \\
(\mathrm{cm})\end{array}$ & $\begin{array}{c}\text { Length of } \\
\text { visible peduncle } \\
(\mathrm{cm})\end{array}$ & $\begin{array}{c}\text { Head length } \\
(\mathrm{cm})\end{array}$ & $\begin{array}{c}\text { Height to } \\
\text { head tip } \\
(\mathrm{cm})\end{array}$ \\
\hline Year: & & & & \\
1996 & $104.1 \mathrm{a}$ & $26.9 \mathrm{a}$ & $8.3 \mathrm{a}$ & $139.2 \mathrm{a}$ \\
1997 & $101.7 \mathrm{~b}$ & $24.1 \mathrm{~b}$ & $6.7 \mathrm{~b}$ & $132.5 \mathrm{~b}$ \\
1998 & $99.3 \mathrm{c}$ & $23.4 \mathrm{~b}$ & $7.5 \mathrm{c}$ & $130.2 \mathrm{~b}$ \\
Seeds m ${ }^{-2} \mathrm{n}$ & & & & \\
300 & $102.7 \mathrm{a}$ & $25.1 \mathrm{a}$ & $7.7 \mathrm{a}$ & $135.6 \mathrm{a}$ \\
500 & $102.4 \mathrm{a}$ & $24.8 \mathrm{a}$ & $7.5 \mathrm{a}$ & $134.7 \mathrm{a}$ \\
700 & $99.9 \mathrm{~b}$ & $24.5 \mathrm{a}$ & $7.2 \mathrm{~b}$ & $131.7 \mathrm{~b}$ \\
\hline
\end{tabular}


Vol. 11 (2002): 153-161.

Table 5. Effect of CCC treatment on height from soil surface to the uppermost leaf ligule and to the head tip and length of visible peduncle and head in spring rye in 1996, 1997, and 1998. Means within each year not followed by the same letter are significantly different at $\mathrm{P} \leq 0.05$.

\begin{tabular}{lcccc}
\hline & $\begin{array}{c}\text { Height to } \\
\text { leaf ligule } \\
(\mathrm{cm})\end{array}$ & $\begin{array}{c}\text { Length of } \\
\text { visible peduncle } \\
(\mathrm{cm})\end{array}$ & $\begin{array}{c}\text { Head length } \\
(\mathrm{cm})\end{array}$ & $\begin{array}{c}\text { Height to } \\
\text { head tip } \\
(\mathrm{cm})\end{array}$ \\
\hline $\begin{array}{l}\text { 1996: } \\
\text { Control }\end{array}$ & & & \\
CCC & $103.2 \mathrm{a}$ & $28.2 \mathrm{a}$ & $8.1 \mathrm{a}$ & $139.6 \mathrm{a}$ \\
$1997:$ & $104.9 \mathrm{a}$ & $25.6 \mathrm{~b}$ & $8.4 \mathrm{a}$ & $138.8 \mathrm{a}$ \\
$\quad$ Control & & & & \\
CCC & $103.3 \mathrm{a}$ & $25.8 \mathrm{a}$ & $6.7 \mathrm{a}$ & $135.8 \mathrm{a}$ \\
$1998:$ & $101.7 \mathrm{~b}$ & $22.4 \mathrm{~b}$ & $6.7 \mathrm{a}$ & $129.2 \mathrm{~b}$ \\
Control & & & & \\
CCC & $100.1 \mathrm{a}$ & $24.6 \mathrm{a}$ & $7.5 \mathrm{a}$ & $131.8 \mathrm{a}$ \\
\hline
\end{tabular}

$\mathrm{CCC}=$ chlormequat chloride

ligule were negligible. In 1997 , the $6 \%$ reduction in plant height was associated with a reduction in lodging of 35 percentage units (Table 6). In 1998, when heavy rainfall (Table 2) resulted in fully lodged plant stands, CCC treated plants lodged similarly to the control plants.

There was significant year $\times$ PGR $\times$ seeding rate interaction for total number of tillers on main shoots $\left(\mathrm{F}_{2}=2.56, \mathrm{P}<0.008\right)$, number of head-bearing tillers on main shoots $\left(\mathrm{F}_{2}=\right.$ $3.34, \mathrm{P}<0.049)$, vegetative phytomass on tillers $\left(\mathrm{F}_{2}=2.91, \mathrm{P}<0.070\right)$, grain yield produced by tillers $\left(\mathrm{F}_{2}=3.40, \mathrm{P}<0.047\right)$, and tiller contribution to grain yield $\left(\mathrm{F}_{2}=3.37, \mathrm{P}<0.048\right)$. In 1997 when there was a drought (Table 2), CCC enhanced tillering, tiller growth and yield production at 500 and 700 seeds $\mathrm{m}^{-2}$, but inhibited them at 300 seeds $\mathrm{m}^{-2}$ in contrast to the general trend in 1998 when rainfall was heavy. CCC treatment did not affect any of the main shoot yield components.

Seeding rate significantly affected many of the traits characterising the structure of the spring rye plant stands. Increase in seeding rate resulted in fewer tillers and head-bearing tillers, less vegetative phytomass and reduced grain yield on main shoots and tillers. There was lower tiller contribution to grain yield, fewer grains per main shoot head, more heads $\mathrm{m}^{-2}$ (Tables 3 and 7), reduced plant height traits (Table 4) and increased lodging sensitivity (Table 6). Even though significant year $\times$ seeding rate interaction was established for length of pre-heading $\left(\mathrm{F}_{4}=2.47, \mathrm{P}<0.056\right)$ and post-heading periods $\left(\mathrm{F}_{4}=3.62, \mathrm{P}<0.011\right)$, only negligible effects on duration of growth phases were recorded (Table 1).

Table 6. Effect of seeding rate and CCC treatment on lodging of spring rye stands (\%) in 1996, 1997, and 1998. Means within each year and treatment not followed by the same letter are significantly different at $\mathrm{P} \leq 0.05$.

\begin{tabular}{|c|c|c|c|}
\hline & 1996 & 1997 & 1998 \\
\hline \multicolumn{4}{|l|}{ Seeds $\mathrm{m}^{-2}$ : } \\
\hline 300 & $34 \mathrm{c}$ & $23 c$ & $90 \mathrm{a}$ \\
\hline 500 & $50 \mathrm{~b}$ & $40 \mathrm{~b}$ & $89 a$ \\
\hline 700 & $70 \mathrm{a}$ & $60 a$ & $91 \mathrm{a}$ \\
\hline \multicolumn{4}{|c|}{ PGR treatment: } \\
\hline Control & $55 \mathrm{a}$ & $58 \mathrm{a}$ & $90 a$ \\
\hline $\mathrm{CCC}$ & $48 \mathrm{a}$ & $24 b$ & $90 \mathrm{a}$ \\
\hline
\end{tabular}

$\mathrm{CCC}=$ chlormequat chloride 


\section{Peltonen-Sainio, P. et al. Yield formation of spring rye}

Table 7. Seeding rate effect on tiller growth and tiller contribution to grain yield of spring rye in 1997 and 1998 . Means within each and among both treatments not followed by the same letter are significantly different at $\mathrm{P} \leq 0.05$.

\begin{tabular}{|c|c|c|c|c|c|c|c|c|c|c|}
\hline \multirow[t]{2}{*}{ Seeds $\mathrm{m}^{-2}$} & \multicolumn{2}{|c|}{$\begin{array}{l}\text { Total number of } \\
\text { tillers per main } \\
\text { shoot } \\
\text { (no.) }\end{array}$} & \multicolumn{2}{|c|}{$\begin{array}{l}\text { Head-bearing tillers } \\
\text { per main shoot } \\
\text { (no.) }\end{array}$} & \multicolumn{2}{|c|}{$\begin{array}{l}\text { Vegetative } \\
\text { phytomass on tillers } \\
\text { (g per main shoot) }\end{array}$} & \multicolumn{2}{|c|}{$\begin{array}{c}\text { Grain yield on } \\
\text { tillers } \\
\text { (g per main shoot) }\end{array}$} & \multicolumn{2}{|c|}{$\begin{array}{l}\text { Contribution of } \\
\text { tillers to grain yield } \\
(\%)\end{array}$} \\
\hline & Control & $\mathrm{CCC}$ & Control & $\mathrm{CCC}$ & Control & $\mathrm{CCC}$ & Control & $\mathrm{CCC}$ & Control & $\mathrm{CCC}$ \\
\hline \multicolumn{11}{|l|}{ 1997: } \\
\hline 300 & $1.16 \mathrm{a}$ & $0.91 b$ & $0.68 \mathrm{a}$ & $0.54 \mathrm{a}$ & $0.84 a$ & $0.59 b$ & $0.57 \mathrm{a}$ & $0.39 b$ & $0.32 \mathrm{a}$ & $0.23 b$ \\
\hline 500 & $0.70 \mathrm{~cd}$ & $0.78 b c$ & $0.26 \mathrm{~b}$ & $0.34 b$ & $0.25 c$ & $0.37 \mathrm{c}$ & $0.15 \mathrm{~d}$ & $0.25 \mathrm{c}$ & $0.12 \mathrm{c}$ & $0.17 b c$ \\
\hline 700 & $0.36 \mathrm{e}$ & $0.62 \mathrm{~cd}$ & $0.12 b c$ & $0.31 b$ & $0.07 \mathrm{~d}$ & $0.26 \mathrm{c}$ & $0.04 \mathrm{e}$ & $0.16 \mathrm{~d}$ & $0.04 \mathrm{~d}$ & $0.13 \mathrm{c}$ \\
\hline \multicolumn{11}{|l|}{ 1998: } \\
\hline 300 & $0.70 \mathrm{a}$ & $0.74 \mathrm{a}$ & $0.63 a$ & $0.70 \mathrm{a}$ & $0.71 \mathrm{a}$ & $0.72 \mathrm{a}$ & $0.21 \mathrm{a}$ & $0.23 \mathrm{a}$ & $0.30 \mathrm{a}$ & $0.33 \mathrm{a}$ \\
\hline 500 & $0.64 a$ & $0.68 \mathrm{a}$ & $0.59 \mathrm{ab}$ & $0.63 a$ & $0.57 \mathrm{ab}$ & $0.56 \mathrm{ab}$ & $0.17 \mathrm{ab}$ & $0.17 \mathrm{ab}$ & $0.26 \mathrm{a}$ & $0.29 \mathrm{a}$ \\
\hline 700 & $0.56 \mathrm{ab}$ & $0.48 b$ & $0.48 b c$ & $0.42 b c$ & $0.35 b c$ & $0.33 b c$ & $0.09 \mathrm{~b}$ & $0.10 \mathrm{~b}$ & $0.16 b$ & $0.17 b$ \\
\hline
\end{tabular}

$\mathrm{CCC}=$ chlormequat chloride

\section{Discussion}

The results indicated that under southern Finnish growing conditions, spring rye has high yield potential, but its realisation greatly depends on precipitation and lodging of the plant stands. The long-strawed rye cultivar Ovid lodged by $41 \%$, $52 \%$, and $90 \%$ (Table 6) and produced grain yields of 5,400, 3,100, and 2,000 kg ha-1 in 1997, 1996, and 1998, respectively. These annual differences in lodging sensitivity did not result from concomitant and marked differences in plant height, which varied only modestly, from 130 to $139 \mathrm{~cm}$. Thus, the amount of precipitation during the growing season was considered to determine lodging in these studies. In addition to this, the recorded absence of the height effect suggests that other traits such as strength of the basal internodes and extent of the root plate per shoot had impact on lodging, shoot leverage and anchorage as recently shown by Berry et al. (2000).

Heavy rainfall was likely to interfere with yield formation of spring rye under Finnish growing conditions. For example, grain yield was highest in 1997, when precipitation was below and temperature above the long-term average for most of the growing season (Table 2).
Under such growing conditions, the pre-heading period was up to 12 days and the post-heading period up to six days shorter than in 1998 (Table 1). In spite of this, the grain yield in a dry year like 1997 was more than double that in 1998, a year with ample precipitation.

The results also indicated that the evident drought during post-heading in 1997 did not restrict grain-filling. In 1996 the total weight of grains per main shoot head was only $60 \%$ and in $199843 \%$ of that recorded in 1997 (Table $3)$. This markedly contributed to the grain:straw ratio. In 1996 the main shoot HI was 11.5 percentage units, and in 199816.2 percentage units, lower than in 1997. These results may indicate that the long-strawed spring rye cultivar Ovid has a root system able to penetrate into deep soil layers and thereby able to maintain water uptake even during drought periods. Such a high grain yield and main shoot head weight in 1997 could also result from less competition between plants, since a low numbers of heads $\mathrm{m}^{-2}$ were recorded compared to 1996 and 1998 (Table 3).

In general, the long-strawed spring rye cultivar Ovid had high vegetative phytomass compared with grain yield and HI ranged from $27 \%$ to $43 \%$ depending on year. For the same years, 1996-1998, modern spring sown cultivars (10 
Vol. 11 (2002): 153-161.

to 12 depending on species) of wheat had HI values of 35-47\%, oat (Avena sativa L.) 43-53\%, two-rowed barley $47-57 \%$, and six-rowed barley $50-61 \%$ in southern Finland (unpublished data). This inefficient translocation of photoassimilates to harvestable yield in long-strawed rye cultivars is likely to be one of the major reasons for the relatively modest yield gains in winter rye ( $1.38 \%$ p.a.) compared with other cereal species (1.78 to $1.91 \%$ p.a.) as shown by Slafer and Peltonen-Sainio (2001). Straw shortening and concomitant increase in the proportion of grain in the phytomass and lodging resistance in winter and spring rye may result in increased drought sensitivity.

\section{Plant growth regulation effects}

Treatments with anti-lodging agents to shorten and stiffen cereal straw may represent an efficient way to increase yield stability in spring rye, in which lodging markedly interferes with buildup and/or realisation of yield potential. In this study, rye plants treated with CCC were shorter than the controls, but the reduction in height was modest: only $1-6 \%$, corresponding to ca. $1-7 \mathrm{~cm}$ depending on year (Table 5). Moreover, Kurten et al. (1972) reported relatively slight reductions in straw length and stand capacity in response to CCC treatment in winter rye. Reduction in height of spring rye was principally due to CCC induced inhibition of elongation in the visible part of the uppermost internode, while no consistent effects on head length and height to the uppermost leaf ligule were established. Naylor (1989) reported that CCC restricted elongation of the upper internodes of triticale (X Triticosecale Wittmack) stems. Even though the CCC induced shortening of straw was modest, it was associated with lodging resistance, which increased by 35 percentage units in 1997 (Table 6 ), when low precipitation did not cause severe lodging. However, in 1998, abundant precipitation (Table 2) resulted in completely lodged plant stands, and CCC treated plants lodged similarly to controls.
Applying CCC increased the grain yield of spring rye by ca. $200 \mathrm{~kg} \mathrm{ha}^{-1}$ (average grain yield for control stands was $3,400 \mathrm{~kg} \mathrm{ha}^{-1}$ and for CCC treatment stands $3,600 \mathrm{~kg} \mathrm{ha}^{-1}$ ). This was primarily due to reduced lodging, as CCC treatment neither prolonged the pre- and post-heading periods (Table 1) nor altered yield components markedly. Both of these findings recorded under long day conditions are contrary to those of Naylor (1989), who found that CCC delayed leaf senescence and resulted in more grains per head in triticale. Kurten et al. (1972) also reported that CCC application resulted in more grains per head in winter rye.

In addition to shortening the straw, CCC affected tiller growth, but the effect was dependent on year and seeding rate (Table 7). When there was drought, CCC treatment tended to enhance tillering as well as tiller growth and yield formation at 500 and 700 seeds $\mathrm{m}^{-2}$, while inhibiting them at 300 seeds $\mathrm{m}^{-2}$ when compared with the control. Under conditions of heavy rainfall in 1998, a contrary effect, or lack of response to CCC treatment, was established depending on the trait measured. The cause of such differing responses to CCC treatment is, however, difficult to explain on the basis of only two very contrasting years.

\section{Seeding rate effects}

Plant stand structure of spring rye responded markedly to seeding rate without, however, affecting grain yield. Thus, spring rye was flexible and well able to utilise the available space through tillering. The number of heads $\mathrm{m}^{-2}$ increased when higher seeding rates were used (Table 3). This indicates that even though tillering and tiller growth were markedly enhanced at lower seeding rates (Table 7), tillers were unable to fully compensate for the reduced number of main shoots $\mathrm{m}^{-2}$. However, in addition to stimulating tiller growth and productivity, as also indicated by Berry et al. (2000) and Whaley et al. (2000), a low seeding rate markedly enhanced grain yield of the primary heads (Table 3 ). For 


\section{Peltonen-Sainio, P. et al. Yield formation of spring rye}

example, a decrease in seeding rate from 700 to 300 seeds $\mathrm{m}^{-2}$ resulted in four more grains per primary head, $17 \%$ higher head weight and a tendency of up to $18 \%$ increased head filling rate (data not shown). This enhanced tiller and main shoot growth at the lower seeding rates, which influenced that impact of seeding rate on grain yield, may result from greater radiation use efficiency following better radiation distribution through the canopy and increased canopy nitrogen ratio as proposed by Whaley et al. (2000).

Seeding rate only affected duration of different growth phases by a maximum of one day (Table 1). Thus, growth duration of spring rye did not respond to seeding rate as markedly and consistently as did e.g. spring oat grown at high latitudes. Peltonen-Sainio and Järvinen (1995) indicated that the use of high seeding rates resulted in up to 5 days shorter duration of period from sowing to yellow-ripe. Our results indicated that the enhanced tillering of spring rye at 300 seeds $\mathrm{m}^{-2}$ did not result in uneven ripening of plant stands.

Even though there were no significant seeding rate effects on grain yield and single grain weight, it is interesting to note that there was a tendency that at the lower seeding rate, the grain yield and grain weight were higher, and not vice versa. This gives more emphasis to the finding that when spring rye is sown, there is no need to use seeding rates higher than 300 viable seeds $\mathrm{m}^{-2}$. This is far less than recommended for other spring cereals grown in Finland (e.g., Mela and Paatela 1974, Peltonen-Sainio and Järvinen 1995). Furthermore, it was evident that at higher seeding rates the increased tendency to lodge was an important factor affecting yield formation. When studying lodging-associated plant characteristics Berry et al. (2000) found that use of lower seeding rates in winter wheat increased stem diameter, but reduced the material strength of stem slightly. However, use of lower seeding rates increased anchorage of the wheat plants due to more spreading and deeper root plate (Berry et al. 2000). In this study, seeding rate did not affect grain weight $\left(\mathrm{F}_{2}=0.63, \mathrm{P}<0.539\right)$ or hectolitre weight $\left(\mathrm{F}_{2}=0.91, \mathrm{P}<0.411\right)$ suggesting that use of low seeding rates did not have adverse effects on spring rye quality.

In conclusion, results from this study indicated that spring rye, a novel spring cereal in northern agriculture, has high yield potential, but lodging restricts its expression. By using low seeding rates of 300 viable seeds $\mathrm{m}^{-2}$, yield formation of both main shoots and tillers were enhanced and lodging was prevented without delaying harvesting and affecting grain yield, grain weight or hectolitre weight.

\section{References}

Berry, P.M., Griffin, J.M., Sylvester-Bradley, R., Scott, R.K., Spink, J.H., Baker, C.J. \& Clare, R.W. 2000. Controlling plant form through husbandry to minimise lodging in wheat. Field Crops Research 67: 59-81.

Froment, M.A. \& McDonald, H.G. 1997. Effect of a plant growth regulator regime on internode length and weight of tillers in conventional and hybrid rye and the impact of nitrogen on crop performance. Journal of Agricultural Science 128: 143-154.

Heyland, K.U. \& Aufhammer, W. 1973. Yield formation in winter rye. Zeitschrift für Acker- und Pflanzenbau 137: 96-122.

Kurten, P.W., Schuster, W. \& Kuhn, H. 1972. Field experiments on the use of chlorcholine chloride (CCC) with winter rye. Zeitschrift für Acker- und Pflanzenbau 135: 29-42.

Littell, R.C., Milliken, G.A., Stroup, W.W. \& Wolfinger, R.D.
1996. SAS System for Mixed Models. Cary, NC: SAS Institute Inc. $633 \mathrm{p}$.

Mela, T. \& Paatela, J. 1974. Grain yield of spring wheat and oats as affected by population density. Annales Agriculturae Fenniae 13: 161-167.

Mukula, J. \& Rantanen, O. 1989a. Climatic risks to the yield and quality of field crops in Finland. III. Winter rye 1969-1986. Annales Agriculturae Fenniae 28: 311.

Mukula, J. \& Rantanen, O. 1989b. Climatic risks to the yield and quality of field crops in Finland. IV. Winter wheat 1969-1986. Annales Agriculturae Fenniae 28: 13-19.

Naylor, R.E.L. 1989. Effects of the plant growth regulator chlormequat on plant form and yield of triticale. Annals of Applied Biology 114: 533-544.

Peltonen-Sainio, P. \& Järvinen, P. 1995. Seeding rate 
Vol. 11 (2002): 153-161.

effects on tillering, grain yield, and yield components of oat at high latitude. Field Crops Research 40: 4956.

Peltonen-Sainio, P. \& Rajala, A. 2001. Chlormequat chloride and ethephon affect growth and yield formation of conventional, naked and dwarf oat. Agricultural and Food Science in Finland 10: 165-174.

Rajala, A. \& Peltonen-Sainio, P. 2000. Manipulating yield potential in cereals by plant growth regulators. In: Basra, A.S. (ed.). Growth Regulators in Crop Production. Food Products Press, Binghamton, New York, USA. p. 27-70.

Slafer, G.A. \& Peltonen-Sainio, P. 2001. Yield trends of temperate cereals in high latitude countries from 1940 to 1998. Agricultural and Food Science in Finland 10: $121-131$.

Sturm, H. 1975. Nutritional status and the effect of growth regulators. Zeitschrift für Acker- und Pflanzenbau 141:71-84.

Zadoks, J.C., Chang, T.T. \& Konzak, C.F. 1974. A decimal code for the growth stages of cereals. Weed Research 14: 415-421.

Whatley, J.M., Sparkes, D.L., Foulkes, M.J., Spink, J.H., Semere, T. \& Scott, R.K. 2000. The physiological response of winter wheat to reductions in plant density. Annals of Applied Biology 137: 165-177.

\title{
SELOSTUS
}

\section{Kylvötiheyden ja kasvunsääteiden vaikutus kevätrukiin satoon}

\author{
Pirjo Peltonen-Sainio, Ari Rajala ja Susanna Muurinen \\ Helsingin yliopisto
}

Kolmivuotisessa kokeessa tutkittiin kylvötiheyden ja
kasvunsääteiden vaikutusta kevätrukiin satoon Etelä-
Suomen kasvuoloissa. Kokeet järjestettiin Helsingin
yliopiston Viikin koetilalla. Kylvötiheydet olivat ko-
keessa 300,500 tai 700 itävää siementä neliömetril-
lä, ja kasvustot joko käsiteltiin kasvunsääteellä [klor-
mekvattikloridi (CCC)] tai ei.
Tutkittu saksalainen kevätruislajike Ovid oli hy-
vin pitkäkortinen ja altis lakoontumaan. CCC-käsit-
tely lyhensi kortta ja vähensi lakoontumista vuosina,
jolloin runsas sade ei aiheuttanut kasvustojen lähes
täydellistä lakoontumista. Keskimäärin CCC-käsittely
paransi satoa 200 kg ha ${ }^{-1}$. Paras kevätruissato (5200
${\text { kg ha }{ }^{-1} \text { ) saatiin normaalia lämpimämpänä ja vähäsa- }}_{\text {teisempana kasvukautena (1997), vaikka tähkälle tulo }}$ oli muihin vuosiin verrattuna enimmillään jopa 12 päivää ja jyvän täyttymisaika kuusi päivää lyhyempi.

Kylvötiheys ei vaikuttanut sadon määrään, vaikka eri kylvötiheyksillä kasvusto olikin hyvin erilainen. Mitä alhaisempi kylvötiheys, sitä voimakkaammin kasvusto versoi ja sitä enemmän versoista saatiin satoa, mutta myös pääverson sato parani olennaisesti alhaista kylvösiemenmäärää käytettäessä. Tutkimustemme perusteella kevätruista ei ole syytä kylvää tiheämpään kuin 300 siementä neliömetrille, koska pitkäkortisena kevätruis on hyvin laonaltis, ja koska versominen kompensoi muita kevätviljoja paremmin harvan kylvön ilman, että kasvusto tuleentuisi epätasaisesti. 